\title{
On The Relationship between Listening and Speaking Grades of AL-Balqa Applied University English as a Foreign Language Students
}

\author{
Tamador K. Abu-Snoubar ${ }^{1}$ \\ ${ }^{1}$ Department of English Language and Literature, Al-Balqa Applied University, Jordan \\ Correspondence: Tamador K. Abu-Snoubar, Department of English Language and Literature, Al-Salt Faculty for \\ Humanities, Al-Balqa Applied University, Jordan. E-mail: tamadorenglish@bau.edu.jo
}

\author{
Received: July 28, $2017 \quad$ Accepted: August 30, $2017 \quad$ Online Published: November 28, 2017 \\ doi:10.5539/ies.v10n12p130 URL: https://doi.org/10.5539/ies.v10n12p130
}

\begin{abstract}
This paper aims at exploring the relation between the two skills of listening and speaking. In addition, it tries to investigate the presence of any gender differences in this relation. To achieve these ends, the listening and speaking exams marks of (122) EFL students registered in the English 102 on-line compulsory course were analyzed using SPSS. The findings proved the existence of a positive relation between the two skills $(\mathrm{r}=0.433)$. The Independent Sample T-Test also proved that there were significant statistical differences at $(\alpha \leq 0.05)$ level due to gender differences in the correlation between the listening and speaking abilities among Al-Balqa Applied University EFL students in favor of the females.
\end{abstract}

Keywords: English as a foreign language (EFL), gender, listening, relationship, speaking

\section{Introduction}

\subsection{Background}

Listening and speaking are the most neglected skills in English classes at all levels in Jordan. Although teachers and instructors say that their aim is to turn out students who can both listen and speak very well, the real product does not meet this end.

Jordanian English as a Foreign Language (EFL) students reach universities after laboring for twelve years in a second-secondary-certificate exam oriented way of teaching. This population of unskilled listeners and non-proficient speakers find that the situation in EFL classes at the institutions of higher education is not different. Large teacher-centered classes, untrained instructors, poor installment of technology, time constrains, emphasis on the quantity of the material covered and traditional methods of assessment still govern what goes on inside EFL classes. Instructors' individual efforts usually do not count because they find themselves governed by the policy of conducting unified exams meant to guarantee the greatest degree of equality among the students. These procedures suffocate any efforts to give the skills of listening and speaking the attention they deserve.

The large number of graduates will definitely start searching for jobs, and one of the main qualifications needed to get any chance in the market in Jordan, as in most of the other countries, is to be good in English. Being good in English, however, doesn't mean having a good command of grammar any more, it means being able to communicate fluently in this foreign language. Employers recommend that graduates need training in such topics as speaking and listening, "persuasion techniques, conflict management and interpersonal communication." Recruitment has proved to be highly related to the applicants' rate of communication skills. Oral communication is not only the most important precondition in evaluating applicants for jobs, but it is also the most important quality of successful managers (Ihmeideh, AL-Omari \& AL-Dababneh 2010). Depending on these facts, the skills of listening and speaking should be allowed more space in EFL classes at schools and universities.

\subsection{Teaching and Testing of the Listening Skill}

Listening is the skill that receives the least attention in EFL classes in Jordan. The reasons behind this situation spring from two sources. The first is the deeply rooted belief found among our teachers that teaching reading can replace listening since both skills are considered to be input skills. Many researchers have tried to attack this idea, such as Gilakjani and Ahmadi (2011), Bozorgian (2012), Celik and Yavuz (2015). The second reason is related to the procedures needed to teach and test this skill. Teaching listening needs small classes and special equipment (C.D. players, speakers and listening laboratories,...). Many hardworking teachers have overcome these 
problems by relying on online listening resources, however. Abbas (2013) conducted an experimental study at AL-Quds Open University in which she investigated the students' attitudes towards an intensive online listening training course. The researcher provided the participants with a wide variety of on-line listening activities that they were supposed to practice at home, in addition to the activities that were done in-class (activities provided by the textbook), but the bulk of the activities were done on-line. Through their logs and their responses to a pre-designed questionnaire, the students realized the importance of sustainable exercise and practice at home. They also reported that this practice has minimized their fear and anxiety during the listening exams. The participants also reported that the online practice has positively affected their oral communication skills. This study has provided evidence that the traditional complaint about the procedural difficulties hindering the efficient teaching of this skill can be easily overcome.

Testing listening produces some other procedural difficulties. Listening tests vary from comprehension questions to true-false and gap-filling questions. Celik and Yavuz (2015) divided these testing problems into internal and external. The internal problems stem from the learner himself and are due to factors like stress and anxiety and the suitability of the listening material, while the external ones have to do with the quality of the listening material and the noisy surroundings.

\subsection{Teaching and Testing of the Speaking Skill}

In today's world where English is the dominating language and nearly the only means of communication in the areas of science, technology, trade and commerce, nobody can deny the fact that oral communication is of prime importance. This intensifies the need for giving the speaking skill more space and attention in our EFL classes. Radwan (2012) highlights the fact that this productive skill is not given enough attention and is being taught in the wrong way. The reason behind these mal-teaching procedures is the teachers' disbelief in the importance of this skill in addition to their inability to speak English fluently, minimizing their chances to be creative teachers of this oral skill.

EFL teachers in Jordan are still faithful to the Grammar Translation Method (GTM) and they still manage their classes depending on the teacher-centered strategies. EFL instructors still believe that teaching listening is time consuming and not rewarding (Hassan, 2001; Azizifar, Ghaitasi, \& Gohary, 2014). Factors hindering the teaching and testing processes of speaking are both internal and external. In a study under the title "Demotivating Factors on English Speaking Skill: A Study of EFL Language Learners and Teacher's Attitudes" by Soureshjani and Riahipour (2012), the participants reported that factors related to the teachers, and equipment and class utility are the three factors that most hinder development of their speaking skill. "Teacher's getting angry" is the highest demotivating factor followed by the "teachers' discriminating between poor and strong students" and "not using the suitable equipment and materials," respectively. The study highlighted the importance of using suitable listening equipment and materials to promote the development of the speaking skill since the students become more willing to speak when they $\mathrm{s}$ hear the words pronounced in a native or native-like way. Liu and Jackson (2008) proved that during oral tests, EFL students usually suffer high rates of anxiety due to their fear of making mistakes and of being over-corrected by their teachers. Another problem that hinders the testing of speaking is that a lot of time is needed to test large classes which strengthen the instructors' belief that teaching and testing this skill is a waste of time. These problems can be avoided, however, by employing computer assisted oral tests which have proved to save time and lower the rates of anxiety among EFL students (Sayin, 2015).

It is important here to highlight the fact that Jordan is one of the EFL countries, which means that English is not heard and used everywhere most of the time. This underlines the need for more concentration on the listening skill since it is the only source for EFL learners to get acquainted with the authentic English language to be able to promote and develop their oral skills.

While this paper is meant to shed light on the possible relation between these two skills through a quantitative analysis of the grades obtained by EFL students in the listening and speaking exams, it also aims at probing the effect of gender on this relation. The role of gender in the teaching and testing of listening and speaking has been overlooked by researchers in general (Lee, 2008, Sobhani, 2015). Valencia (2011) believes that the results obtained from the very limited number of studies in this field, are still inconclusive and shallow.

\subsection{Statement of the Problem}

The relation between listening and speaking and how listening proficiency positively affects the oral skills in general still need more efforts to bridge the gap in our knowledge concerning this area. What effects gender has on this relation is also a route scarcely trodden by researchers and still needs further exploration. This study is hoped to be a contribution in the efforts and body of research meant to enhance the teachers' and instructors' 
belief in the importance and benefits of giving enough time and attention to the listening skill which serves as the corner stone in any attempts to promote their students' oral proficiency.

\subsection{Theoretical Frame}

The two skills of listening and speaking in fact, are inter-related. It is suggested by many researchers like Bozorgian (2012) and Feyten (1991) and Richard (2008) that enhancing the speaking skill is strongly related to the students' progress in the listening skill. Celik and Yavuz (2015) say that understanding the nature of the language skills and how related they are a precondition for any successful learning / teaching process. The order they suggest for dealing with the four skills is listening, speaking, reading and writing. Zhang (2009) relies on Krashen's Input Hypothesis to highlight how listening affects improving the learners' oral fluency. She also adds that only through listening to authentic materials by native speakers can learners produce correct pronunciation and learn how to improve their use of features like stress and intonation. A point supported by Bozorgian (2012) and Abbas (2013) who believe that listening is the basic and most essential skill in any English language process and that it has to be treated with more care and given more time.

\subsection{Aim of the Study}

This study aimed to investigate the relation between the listening and speaking skills through analyzing the grades obtained by the students in the exams dealing with these two skills. The current study also probes any significant differences in this relation due to gender.

\subsection{Significance of the Study}

Although much ink has been shed on the studies dealing with the reading and writing skills and the effective methods and strategies to improve the EFL students' abilities in these areas, listening and speaking continue to be neglected both in practice and in the amount of research allotted to them. The current study turns the spotlight on these skills and tries to bridge the gap and minimize the deficit in the research catering for these skills by investigating the relation between the listening grades and the speaking grades of a sample of AL-Balqa Applied University EFL students, in addition to investigating the role of gender differences in this relation.

\subsection{Study Questions}

This study aims to answer the following questions :

1) Is there a significant relation between the listening and speaking grades among AL-Balqa Applied University EFL Students?

2) Are there significant differences in the correlation between the listening and speaking grades among AL-Balqa Applied University EFL Students due to gender?

\subsection{Limitations of the study}

The current study is limited to Al-Balqa Applied University students / the center colleges, during the second semester of the academic year 2016-2017.

\section{Literature Review}

\subsection{The Effect of Listening on Speaking}

The effect of the learners' listening abilities on their oral skills and speaking abilities has attracted the attention of many researchers in EFL and ESL countries. Celik and Yavuz (2015) conducted a study to find the correlation between speaking and listening grades at university level. To carry out this study, the participants who belonged to different scientific fields of study were allowed a six-hour training of listening per week for fourteen weeks. It included listening to short passages followed by different activities. At the end of the term, they set for a listening exam and an oral speaking exam. The correlation between the speaking and the listening grades proved to be very low, contrary to the researchers' expectations.

Zhang (2009) investigated the effects of listening on speaking for Chinese college students. The quantitative analysis of the correlation between the grades obtained by the listening and speaking tests proved that the two abilities are closely related which means that listening does have a positive effect on improving the participants' oral skills.

Bozorgian (2012) conducted a study to shed light on the relationship between listening and other language skills in International English Language Testing System (IELTS). The grades of 701 participants in the IELTS were downloaded from www.ieltstehran.com. The descriptive analysis demonstrated that the lowest grades of all the skills were those of the speaking skill $(\mathrm{M}=5.568$, S.D. $=0.889)$ and the highest marks were obtained in the reading skill $(\mathrm{M}=6.987$, S.D. $=0.789)$. The pairwise correlation coefficient proved the existence of a strong 
positive correlation between listening and speaking $(\mathrm{r}=0.654, \mathrm{n}=1800, \mathrm{p} \leq .000)$. The correlation between listening and the overall IELTS performance was $(\mathrm{r}=0.887, \mathrm{n}=1800 \mathrm{p} \leq .000)$.

Astroga-Cabezas (2015) tried to prove the existence of a positive effect for listening on oral skills in English language teaching. The 120 participants were divided into two groups of 60 students. The test group was "provided with totally listening focused instruction and activities," while the second group was taught the normal way. The analysis of the pre-test and post-test scores proved the existence of a strong relation between listening proficiency and a "slight" improvement in the oral skills.

Pinem (2006) examined the correlation between listening as an independent variable with speaking as a dependent variable. The 17 participants did better in the listening exam $(M=5.5688)$ than in the speaking test $(\mathrm{M}=4.8235)$. The Pearson Product-Moment Correlation formula was used and the findings highlighted the presence of a positive correlation between the two variables, $(\mathrm{r}=0.30812)$ proving that a learner's ability in speaking influences the way he/she does in the speaking exams.

Azizah (2014), who strongly believes that speaking is the cream of language teaching and that exposing EFL and ESL learners to authentic listening texts can improve their speaking skills, explored the correlation between listening comprehension and speaking ability. The 31 participants of the English Education Department at Jakarta State University furnished the sample of the study. The statistical analysis proved the existence of a positive correlation between the two variables $\left(\mathrm{r}_{\mathrm{xy}}=0.46\right)$.

Jaiyote (2015) examines the relationship between test-takers' L1, listening proficiency and their performance on paired speaking tests. The 40 participants' mother tongue were Urdu (20 students) and Thai (20 students). The data analyzed in this study were the listening and speaking grades. The results depicted significant correlation between the listening and paired speaking tests. No statistically significant correlation was found between the listening scores and the monologic speaking scores, however.

\subsection{The Effect of Gender on the Relation between Listening and Speaking Grades}

Up to the researcher's knowledge, no studies dealing with the gender differences when it comes to the correlation between listening grades and speaking grades do exist. Many studies have dealt with gender differences in listening comprehension or gender differences in speaking exams. All of these studies remain inconclusive and this field still needs more attention.

\subsubsection{Gender and Listening Grades}

Valencia (2011) carried out a study to investigate the impact of Visually Enriched PowerPoint slides (VEPP) on learner's achievement and to see if gender affected the listening outcomes with or without VEPP. The researcher predicted that VEPP would enhance the students' listening comprehension. The results proved that the (46) participants in the VEPP group earned higher grades than the non-VEPP (45) participants. The researcher's second hypothesis predicted that the use of VEPP in listening activities would have an impact on male (16 participants) and female (30 participants) differently. The analysis uncovered the existence of no effect for gender on the participants' marks.

Jafari (2010) investigated the existence of gender differences in the relationship between Iranian EFL students' listening comprehension (LC) and their English listening comprehension motivation (ELCM). The 32 male and 32 female participants reported no significant differences due to gender neither in the $\mathrm{LC}(\mathrm{t}=-0.784, \mathrm{p}>0.05)$ nor in the ELCM $(\mathrm{t}=-0.007, \mathrm{p}>0.05)$.

In a study by Sepahvand (2012), the relationship between listening self-efficacy, listening comprehension, gender and age was investigated. The 60 participants (30 males and 30 females) who revealed that a relation exists between self-efficacy and listening comprehension, proved that gender did not affect the relationship between self-efficacy and listening comprehension. Age was found to be negatively related to listening self-efficacy.

\subsubsection{Gender and Speaking Grades}

In a study exploring the impact of gender in oral proficiency testing, O'Loughlin (2002) investigated whether the gender of the IELTS test-takers ( 8 males and 8 females) and that of the examiners ( 2 males and 2 females) would affect the scores of the oral proficiency of examinees. The findings revealed that gender did not have a significant impact on the IELTS interview.

Motallebzadeh (2011) investigated the relationship of 429 adult EFL students. After conducting the Oxford placement test and an IELTS oral placement test, the sample was minimized to 160 participants for a final oral interview. Statistical analysis of the data revealed that although females' achievement in the oral test was better 
than the males', the difference was not significant.

Khaghaninejad (2016) probed the role of gender on Iranian intermediate learner' oral accuracy and fluency. The study tried also to explore which group (males or females) has a correlation between its speaking fluency and listening comprehension. The sample consisted of 30 male and 30 female learners who were selected randomly from a pool of an institute of technology. Two raters analyzed the recorded interviews (in terms of fluency and accuracy) after which the participants set for a listening comprehension test, the findings pointed that the female participants exceeded their male counterparts in the fluency part but the males did better in the accuracy part. In addition, a strong relation was found between female participants' listening comprehension and speaking fluency while for the males this relation was traced between their listening comprehension and their speaking accuracy.

\section{Methodology}

\subsection{Participants}

The participants in this study are 122 students (43 males, 79 females). They range from freshmen to seniors of low and high proficiency levels and enrolled in the English 102 on-line compulsory course. They belong to different majors and come from different social classes. The participants' ages range between 18-22 years old.

\subsection{Instrument}

The grades obtained from the on-line multiple choice listening exam (4 questions $=$ four points $)$ and the speaking exam marks as rated by examiners (out of 8 marks).

\subsection{Procedure}

The English 102 advanced service course is a compulsory course that is proceeded by the English 101 intermediate compulsory course and the English 099 remedial course for students who fail the placement test. EFL Students are taught three hours of face-to-face lecture per-week in addition to one online hour in which they are supposed to do online activities uploaded on their accounts by their instructors. The online material consists of seven units and is covered within the 16-week semester. Each unit is allotted nearly two weeks (6-7 face-to-face lectures). Listening is officially allotted one lecturing hour per week in addition to the online listening activities students are recommended to do whether at home or in the EFL computer labs. The students set for their listening exam as part of the mid-semester exam held at the end of the ninth week. The students are allowed to listen twice to a certain listening passage and then they answer the four multiple-choice questions, click the "submit" button and go on to continue the other parts of their exam. Each section is given a different listening comprehension passage of the same degree of difficulty. The texts are authentic-like and the speakers are natives. It is worth mentioning that a special committee of twelve EFL instructors (males and females, M.A and $\mathrm{Ph} . \mathrm{D}$. holders) meets at the beginning of every semester to evaluate the texts used in the previous semester, choose new texts and write down suitable questions. After finishing their exam, students set for their speaking exam. Each student is given a speaking prompt, allowed to think for 2-3 minutes then is allowed to speak in the form of monologue for 2 minutes. The holistic scoring method recommended by Luoma (2004) and Pan and Pan (2011) are the approach used to assess the students. This method of assessment is found to be the most suitable since it combines an overall impression of the rater in addition to its being rapid and accurate.

\subsection{The Selection of the Sample of the Study}

The random sample which consisted of the results obtained by (122) students registered in the English 102 course, was selected from the results of a pool of 900 students recorded on the marks system at Al-Balqa Electronic Academy. The sample of the study was determined based on Sekaran and Bougie (2013).

\subsection{Stability of the Study Instruments}

The researcher used (Cronbach alpha) to measure the stability of the measuring tool. The value (alpha $=82.14 \%$ ) was excellent, being higher than the acceptable $60 \%$ (Miller, 2013).

\subsection{Statistical Analysis}

The data were analyzed via the SPSS (Statistical Package for the Social Sciences), using both descriptive and informational statistics. The following descriptive statistical methods have been used for the purposes of analysis:

1) Percentage: have been used to measure the relative frequency distributions of the characteristics of respondents and their responses to the test questions.

2) The mean: was used as the leading measures of central tendency to measure the average answers of respondents to the test questions. 
3) Standard deviation: was used as one of the measures of dispersion to measure the deviation in the answers of the respondents about the middle of the arithmetic.

4) Independent Samples T-Test: was used to know the differences between the averages of statistical variables of the categories.

\section{Results}

Q1: Is there any significance correlation between the listening and speaking abilities among Al-Balqa Applied University EFL students?

In order to answer this question, as well as to identify the relationship between the listening and speaking abilities among Al-Balqa Applied University EFL students, the researcher tested the correlation coefficient (Pearson), and the level of significance was (0.01). A significant correlation was found between the listening and speaking abilities among Al-Balqa Applied University EFL students.

Table 1. Correlation between the listening and speaking abilities among Al-Balqa Applied University EFL students

\begin{tabular}{cccc}
\hline & & Listening & Speaking \\
\hline \multirow{4}{*}{ Listening } & Pearson Correlation & 1.000 & $0.433^{* *}$ \\
& Sig.(2-tailed) & 0.000 & 0.000 \\
& $\mathrm{~N}$ & 122 & 122 \\
\multirow{4}{*}{ Speaking } & Pearson Correlation & 1.000 & $0.433^{* *}$ \\
& Sig.(2-tailed) & 0.000 & 0.000 \\
& $\mathrm{~N}$ & 122 & 122 \\
\hline
\end{tabular}

**Correlation is significant at the 0.01 level.

Table 1 shows that there is a relationship between the variables of the study (listening and speaking) among Al-Balqa Applied University EFL students, where the coefficient of correlation is (0.433), which is statistically significant at level (0.01), and this correlation is positive.

Q2: Are there significant differences in the correlation between the listening and speaking abilities among Al-Balqa Applied University EFL students due to gender?

In order to answer the second research questions, descriptive statistics were used. The descriptive statistics included mean and standard deviations between the listening and speaking abilities among Al-Balqa Applied University EFL students, and the Independent Samples T-Test was used to determine differences between males and females, and Table 2 shows differences due to gender.

Table 2. Independent Samples T-Test for identification of any significant gender differences in the correlation between the listening and speaking abilities among Al-Balqa Applied University EFL students

\begin{tabular}{ccccccc}
\hline \multirow{2}{*}{ Gender } & \multicolumn{2}{c}{ Male } & \multicolumn{2}{c}{ Female } & \multirow{2}{*}{ T } & Sig \\
\cline { 2 - 5 } Section & Mean & S.D & Mean & S.D & & \\
\hline speaking & 5.7215 & 2.1240 & 6.1628 & 1.4949 & 0.844 & 0.040 \\
listening & 1.9620 & .9260 & 2.7907 & .9894 & 1.519 & 0.004 \\
\hline
\end{tabular}

Table 2 shows that there are significant statistical differences at $(\alpha \leq 0.05)$ level due to gender differences in the correlation between the listening and speaking abilities among Al-Balqa Applied University EFL students in favor of the females.

\section{Discussion}

The present study is meant to contribute more knowledge to the field of the relation between the listening and speaking abilities. Concerning the first question in this study "Is there a significant correlation between the listening and speaking grades among AL-Balqa Applied University EFL Students?," the data analysis has proved the existence of a strong positive relation between the listening grades and the speaking grades $(\mathrm{r}=0.433)$. This result supports previous studies investigating the same relation. Zhang (2009) conducted a study to investigate this relation and his findings demonstrated that the two skills are closely related; proving that listening has a 
positive effect on improving the learners' oral skills. The findings of the current study also support Bozorgian (2012) whose participants' grades proved the existence of a strong positive correlation between listening and speaking as well as between listening and the skills of writing and reading. Similar findings were also reached by Astroga-Cabezas (2015) who proved the existence of a positive effect of listening. Azizah (2014) emphasized the existence of a close relation between listening comprehension and the overall language proficiency. A strong positive relation was also found between the grades of the listening and speaking exams. The findings of the present study are also consistent with studies by Pinem (2006), Jaiyote (2015). Celik and Yavuz (2015) whose study hits the same destination, is not supported by findings of the present study, in which the correlation between the two skills proved to be very low.

The findings showed that listening is closely connected to the oral skills and does have an effect on the development of oral proficiency in EFL classes. These results supported educators calling for giving more time and attention for the teaching of listening with hard evidence to rely on.

Concerning the second question "Are there significant differences in the correlation between the listening and speaking grades among AL-Balqa Applied University EFL students due to gender?", the data analysis proved the existence of significant differences in favor of the females. The closest study to the area of the question is the one by Khagjaninejad (2016) which explored the effect of gender on the relation between speaking and listening the findings illustrated that females did better in the fluency side of the oral test while males' achievement was better in the accuracy side. The study also highlighted the existence of a strong relation between the female participants' listening comprehension and speaking fluency. A strong relation between the males' listening comprehension and speaking fluency proved to exist.

Since no other studies dealt with the gender role on the relation between listening and speaking, studies dealing with gender and listening and others dealing with gender and speaking are traced here.

Up to the researcher's knowledge, none of the previous studies is supported by the findings of the present study. The current study proved the existence of significant gender differences in the relation between listening and speaking. Valencia (2011) did not support the effect of gender on the listening skill. The current study is also inconsistent with the findings of Jafari (2010) and Sepahvand (2012) who proved through their studies that gender has no effect on the listening skill. When coming to differences in the oral proficiency grades due to gender differences, the present study is found to be inconsistent with previous studies by O'Loughlin (2002) and Motallebzadeh (2011)

\section{Conclusion}

The findings of the statistical analysis processes show that there is a significance correlation between the listening and speaking abilities among Al-Balqa Applied University EFL students, and there are significant gender differences in the correlation between the listening and speaking abilities among Al-Balqa Applied University EFL students.

In the light of these findings, providing some recommendations is found to be useful.

\subsection{Pedagogical Recommendations}

\subsubsection{Recommendations for Teachers and Instructors}

Based on the results of the current research, teachers are advised to allow their EFL students more exposure to authentic and semi-authentic English listening texts. Listening input in the form of in-class and at-home activities enhances the learners' oral comprehension abilities and lowers their anxiety when it comes to this skill. The instructors' are also recommended utilizing modern technology and relying on on-line resources that allow them to beat any obstacles resulting from logistic shortcomings at schools and universities.

\subsubsection{Recommendations for Students}

Language learners are recommended to enhance their listening input so that they strengthen their speaking skill, pronunciation and vocabulary. Listening activities can be easily accessed these days. A button click on his computer or smart phone allows any serious learner to choose a suitable and interesting listening material and listen to it as many times as he needs and at any time.

\subsection{Recommendations for Future Research}

Emphasizing the relation between the two skills of listening and speaking still needs more research efforts. Researchers are invited to conduct studies with wider samples that employ all sorts of listening materials and to evaluate the best sources, practices and activities that can enhance the learners' oral skills. The water in the lake of the role of gender in this relation needs to be moved and explored through more studies. 


\section{Acknowledgments}

The researcher thanks Mr. Qwaider, IT Manager at Balqa Electronic Academy for his assistance while preparing the random sample used in this research.

\section{References}

Abbas, I. (2013). Investigating the Students' Attitudes Towards Using the Best Practices in English Listening in The Blended E-Learning Environment at Al-Quds Open University. Palestinian Journal of Open \& Distance Education, 4(7). https://doi.org/10.12816/0016342

Astroga-Cabezas, E. (2015). The Relationship Between Listening Proficiency and Speaking Improvement in Higher Education: Considerations in Assessing Speaking and Listening. Higher Learning Research Communications, 5(2), 35-46. https://doi.org/10.18870/hlrc.v5i2.236

Azizah, H. (2014). The Correlation Between Listening Comprehension and Speaking Ability (Bachelor of Arts thesis, Syarif Hidayatullah State Islamic University, Jakarta). Retrieved from http://repository.uinjkt.ac.id/dspace/bitstream/123456789/7185/1/AFIF\%20FAUZI-FITK.pdf

Azizifar, A., Ghaitasi, H., \& Gowhary, H. (2014). EFL Adult Learner's Attitudes Towards Learning Speaking. International Research Journal of Applied and Basic Sciences, 8(10), 1664-1755.

Bozorgian, H. (2012). The Relationship Between Listening and Other Language Skills in International English Language Testing System. Theory and Practice in Language Studies, 2(4), 657-663. https://doi.org/10.4304/tpls.2.4.657-663

Celik, O., \& Yavuz, F. (2015). The Relationship Between Speaking Grades and Listening Grades of University Level Preparatory Students. Procedia, 197, 2137-2140. https://doi.org/10.1016/j.sbspro.2015.07.339

Feyten, C. (1991). The Power of Listening Ability: An Overlooked Dimension in Language Acquisition. The Modern Language Journal, 75(2), 173-180. https://doi.org/10.2307/328825

Gilakjani, A., \& Ahmadi, M. (2011). A Study of Factors Affecting EFL Learners' Comprehension and Strategies for Improvement. Journal of Language Teaching and Research, 2(5), 977-988. https://doi.org/10.4304/jltr.2.5.977-988

Hassan, F. (2001). Attitudes of Tenth Grade Students Towards Speaking English as a Foreign Language in Salfeet District (Master's thesis, An-Najah National University). Retrieved from https://theses.ju.edu.jo/Show_Abstract.aspx?par1=JUF0542775?Page=12

Ihmeideh, F., Al-Omari, A., \& Al-Dababneh, K. (2010). Attitudes Toward Communication Skills among Students'-Teachers' in Jordanian Public Universities. Australian Journal of Teacher Education, 35(4), 1-11. https://doi.org/10.14221/ajte.2010v35n4.1

Jafari,S. (2010). On the Relationship Between Listening Comprehension Motivation and Listening Comprehension Among the Iranian EFL Learners. Retrieved from http://www.translationdirectort.com/articles/articles1994.php

Jaiyote, S. (2015). The Relationship Between Test-Takers' L1, Their Listening Proficiency and Performance on Paired Speaking Tests. English Language Assessment Research Group, British Council. Retrieved from https://www.britishcouncil.org/exam/aptis/research/publications/relationship-between-11-and-listening-profi ciency

Khaghaninejad, M. (2016). Focusing on the Relationship between Speaking Fluency/Accuracy of EFL Learners of Both Genders and their Listening Comprehension. Mediterranean Journal of Social Sciences MCSER Publishing, 7(3), 444-450. https://doi.org/10.5901/mjss.2016.v7n3p444

Lee, J. (2008). Listening Strategies, Listening Proficiency and Gender (Master thesis, University of Oregon). Retrieved from http://linguistics.uoregon.edu/wp-content/uploads/2015/08/Lee-Jung-Soo.pdf

Liu, M., \& Jackson, J. (2008). An Exploration of Chinese EFL Learners' Unwillingness to Language Anxiety. The Modern Language Journal, 92(1), 71-86. https://doi.org/10.1111/j.1540-4781.2008.00687.x

Luoma, S. (2004). Assessing Speaking. Cambridge, UK: Cambrige University Press. http://dx.doi.org/10.1017/CBO97805117733017

Miller, D. (2013). Measurement by the physical educator why and how (3rd ed.). Indianapolis, Indiana, WM. C. Brown Communication, INC.

Motallebzadeh, K. (2011). Does Gender Play a Role in Assessment of Oral Proficiency? English Language 
Teaching, 4(4), 165-172. https://doi.org/10.5539/elt.v4n4p165

O'Loughlin, K. (2002). The Impact of Gender in Oral Proficiency Testing. Language Testing, 19(2), 169-192. https://doi.org/10.1191/0265532202lt226oa

Pan, Y., \& Pan, Y. (2011). Conducting Speaking Tests for Learners of English as a Foreign Language. The International Journal of Education and Psychological Assessment, 5(1), 83-100.

Pinem, Y. (2014). The Correlation Between Listening and Speaking Among High School Students. ELTICS Journal, 1(1), 12-23.

Radwan, R. (2012). Awareness and Attitudes of Gaza Secondary EFL Teachers towards the Methods of Teaching the Speaking Skill (Master's thesis, Al-Azhar University-Gaza). Retrieved from https://www.alazhar.edu.ps/Library/aattachedFile.asp?id_no $=0046110$

Richards, J. (2008). Teaching Listening and Speaking: From Theory to Practice. Retrieved from http://www.professorjackrichards.com/wp-content/uploads/teaching-listening-and-speaking-from-theory-topractice.pdf

Sayin, B. (2015). Exploring Anxiety in Speaking Exams and How it Affects Students' Performance. International Journal of Social Science, 2(12), 112-118.

Sekaran, U., \& Bougie, R., (2013). Research methods for business: A skill-building approach (6th ed.). John Wiley \& Sons.

Sepahvand, M. (2012). The Relationship Between Listening Comprehension, Gender, and Age in EFL Male and Female Learners (Master's Thesis, Shahid Rajaee Teacher Training University Faculty of Humanities). Retrieved from http://idochp2.irandoc.ac.ir/FulltextManager/fulltext15/th/194/194664.pdf

Sobhani, Z. (2015). An Investigation into the Relationship between Gender and Cognitive Listening Comprehension Strategies. JIEB, 20(3), 46-50. Retrieved from http://www.psp-ltd.com/JIEB_20_3_2015.pdf

Soureshjani, K., \& Riahipour, P. (2012). Demotivating Factors on English Speaking Skill: A Study on EFL Language Learners' Attitudes. World Applied Sciences Journal, 17(3).

Valencia, F. (2009). The Power of PowerPoint on Listening Activities on Beginning Spanish Students. Doctoral Dissertation, University of Alabama. Retrieved from http://libcontent1.lib.ua.edu/content/u0015/0000001/0000125/u0015_0000001_0000125.pdf

Zhang, Y. (2009). An Experimental Study of the Effects of Listening on Speaking for College Students. English Language Teaching, 2(3), 194-204. https://doi.org/10.5539/elt.v2n3p194

\section{Appendix 1}

\section{Students' Grades in the Listening and Speaking Tests}

\begin{tabular}{|c|c|c|c|c|c|c|c|c|}
\hline$\#$ & Listening & Speaking & $\#$ & Listening & Speaking & $\#$ & Listening & Speaking \\
\hline 1 & 2 & 4 & 42 & 0 & 2 & 83 & 3 & 4 \\
\hline 2 & 2 & 4 & 43 & 4 & 8 & 84 & 2 & 5 \\
\hline 3 & 3 & 8 & 44 & 4 & 6 & 85 & 2 & 7 \\
\hline 4 & 3 & 8 & 45 & 3 & 6 & 86 & 1 & 5 \\
\hline 5 & 3 & 3 & 46 & 4 & 8 & 87 & 1 & 5 \\
\hline 6 & 3 & 8 & 47 & 3 & 6 & 88 & 2 & 6 \\
\hline 7 & 2 & 4 & 48 & 4 & 6 & 89 & 2 & 6 \\
\hline 8 & 1 & 6 & 49 & 2 & 8 & 90 & 2 & 5 \\
\hline 9 & 2 & 8 & 50 & 4 & 8 & 91 & 4 & 8 \\
\hline 10 & 3 & 6 & 51 & 4 & 7 & 92 & 3 & 8 \\
\hline 11 & 2 & 8 & 52 & 3 & 7 & 93 & 4 & 5 \\
\hline 12 & 3 & 8 & 53 & 4 & 7 & 94 & 3 & 8 \\
\hline 13 & 3 & 8 & 54 & 4 & 8 & 95 & 4 & 7 \\
\hline 14 & 2 & 7 & 55 & 3 & 5 & 96 & 3 & 8 \\
\hline 15 & 2 & 3 & 56 & 4 & 7 & 97 & 1 & 8 \\
\hline 15 & 3 & 4 & 57 & 2 & 7 & 98 & 2 & 6 \\
\hline
\end{tabular}




\begin{tabular}{|l|l|l|l|l|l|l|l|l|}
\hline 16 & 2 & 7 & 58 & 3 & 4 & 99 & 2 & 7 \\
\hline 17 & 3 & 8 & 59 & 3 & 7 & 100 & 2 & 5 \\
\hline 18 & 0 & 4 & 60 & 3 & 8 & 101 & 1 & 6 \\
\hline 19 & 2 & 6 & 61 & 2 & 7 & 102 & 2 & 8 \\
\hline 20 & 1 & 5 & 62 & 4 & 6 & 103 & 2 & 8 \\
\hline 22 & 2 & 7 & 63 & 4 & 5 & 104 & 2 & 7 \\
\hline 23 & 1 & 6 & 64 & 4 & 7 & 105 & 1 & 6 \\
\hline 24 & 4 & 6 & 65 & 3 & 4 & 106 & 2 & 7 \\
\hline 25 & 2 & 7 & 66 & 2 & 6 & 107 & 3 & 8 \\
\hline 26 & 1 & 1 & 67 & 3 & 3 & 108 & 2 & 8 \\
\hline 27 & 3 & 7 & 68 & 3 & 6 & 109 & 2 & 5 \\
\hline 28 & 1 & 8 & 69 & 2 & 6 & 110 & 1 & 5 \\
\hline 29 & 1 & 4 & 70 & 2 & 7 & 111 & 2 & 7 \\
\hline 30 & 2 & 2 & 71 & 2 & 8 & 112 & 1 & 4 \\
\hline 31 & 2 & 7 & 72 & 3 & 6 & 113 & 2 & 5 \\
\hline 32 & 2 & 7 & 73 & 3 & 8 & 114 & 2 & 8 \\
\hline 33 & 1 & 3 & 74 & 2 & 5 & 115 & 2 & 8 \\
\hline 34 & 3 & 8 & 75 & 3 & 6 & 116 & 2 & 5 \\
\hline 35 & 2 & 2 & 76 & 2 & 6 & 117 & 2 & 6 \\
\hline 36 & 2 & 1 & 77 & 2 & 7 & 118 & 2 & 7 \\
\hline 37 & 0 & 0 & 78 & 2 & 3 & 119 & 1 & 5 \\
\hline 38 & 2 & 6 & 79 & 1 & 8 & 120 & 1 & 4 \\
\hline 39 & 3 & 4 & 80 & 2 & 5 & 121 & 1 & 2 \\
\hline 40 & 0 & 1 & 81 & 1 & 7 & 122 & 1 & 3 \\
\hline 41 & 1 & 4 & 82 & 0 & 2 & & & \\
\hline
\end{tabular}

\section{Copyrights}

Copyright for this article is retained by the author(s), with first publication rights granted to the journal.

This is an open-access article distributed under the terms and conditions of the Creative Commons Attribution license (http://creativecommons.org/licenses/by/4.0/). 